\title{
CHLORAMPHENICOL THERAPY IN REACTIONAL LEPROSY
}

\author{
S. Majumdar, B.SC., M.B., B.S. \\ (Medical Officer, Santipara Leprosy Hospital, Assam)
}

In reaction cases in leprosy we previously used intravenous potassium antimony tartrate in a dose of $2 \mathrm{ml}$. of a $2 \%$ solution, in conjunction with $10 \mathrm{ml}$. of $10 \%$ calcium gluconate solution. The course consisted of 6 injections usually and 1 injection of calcium gluconate was given on alternate days. We have also used intravenous mercurochrome, $2 \mathrm{ml}$. of a $1 \%$ solution. Neither of these two therapies gave good results in some cases, and in such cases the reaction could not be arrested. There is also the trouble that if a single drop of potassium antimony tartrate solution escapes into the subcutaneous tissues there is severe pain and swelling. In those cases where the intravenous injections were ineffective, we tried oral capsules of Chloromycetin and the results were good. We then continued with Chloromycetin alone, and the reaction ceased within a few days. Here follow case reports of our experience with Chloromycetin.

Case No. I. LACHI DeBI, F., 25 years. An $\mathrm{L}_{2}$ case, with smears from ears $2+$. On 9.11 .59 she was admitted to the ward with a temperature of $102^{\circ} \mathrm{F}$. $\left(39.9^{\circ} \mathrm{C}\right.$.), also pain the whole body, headache and slight cough. This was all due to lepra reaction. We gave an injection I.V. of $2 \mathrm{ml}$. PAT, with $10 \mathrm{ml}$. of $10 \%$ calcium gluconate I.V. On 10.11.59 the temperature was $101.2^{\circ} \mathrm{F}$. $\left(38.4^{\circ} \mathrm{C}\right.$.). She had body pain and headache, and nodules appeared. On 11.11 .59 again PAT and calcium gluconate I.V. injections were given. The temperature rose to $103.8^{\circ} \mathrm{F}$. $\left(39.9^{\circ} \mathrm{C}\right.$.). On 12.11 .59 the temperature reached $104^{\circ} \mathrm{F}$. $\left(40^{\circ} \mathrm{C}\right.$.). On 13.11.59 we began Chloromycetin 1 capsule twice a day. The temperature was $103^{\circ} \mathrm{F}$. $\left(39.4^{\circ} \mathrm{C}\right.$.). On 14.11 .59 the temperature was $98^{\circ} \mathrm{F}$. $\left(36.6^{\circ} \mathrm{C}\right.$.). Headache and body pain had gone. We kept on the Chloromycetin for 2 more days, the reaction ceased and the general condition of the patient improved.

Case No. 2. Tileswar, M., 19 years. An $\mathrm{L}_{2}$ case, with smears positive $1+$ to $4+$. He was admitted on 14.11 .59 with a temperature of $100^{\circ} \mathrm{F}$. $\left(37.8^{\circ} \mathrm{C}\right.$.), pain in the joints, and crops of new patches appearing. PAT and calcium gluconate injections I.V. on 17.11 .59 when his temperature was $103^{\circ} \mathrm{F}$. $\left(39.4^{\circ} \mathrm{C}\right.$.). On 18.11.59 his temperature was $103.8^{\circ} \mathrm{F}$. $\left(39.8^{\circ} \mathrm{C}\right.$.). On 21.11 .59 he was given PAT and calcium gluconate injections once more with no effect. Chloromycetin was given 1 capsule twice daily from 23.11 .59 and on the next day, 24th, his temperature descended to $96^{\circ} \mathrm{F}$. $\left(36.6^{\circ} \mathrm{C}\right.$.). He had no more joint pain. Chloromycetin was continued for 3 days.

Case No. 3. Daud Munda, male, aged 32 years. An $\mathrm{L}_{3}$ case with bacterial index $3+$ to $4+$. He was warded on 28.11 .59 with temperature of $101^{\circ} \mathrm{F}$. $\left(38.4^{\circ} \mathrm{C}\right.$.) with headache, joint pains and new nodules. Chloromycetin was given, 1 capsule twice daily. On 29.11 .59 his temperature was $99^{\circ} \mathrm{F}$. $\left(37.2^{\circ} \mathrm{C}\right.$.), and on 30.11.59 it was $97.4^{\circ} \mathrm{F}$. $\left(36.3^{\circ} \mathrm{C}\right.$. $)$. Joint pain and headache disappeared and the reaction subsided. We continued Chloromycetin until 2.12.59.

Case No. 4. Robiram Das, male, aged 45 years, an $\mathrm{L}_{3}$ case, with bacterial index $2+$ to $4+$. He was warded on 15.6 .60 with a temperature of $101.6^{\circ} \mathrm{F}$. $\left(38.7^{\circ} \mathrm{C}\right.$.), headache, body pain, and new nodules. He was given PAT and calcium gluconate injections, but the reaction did not yield, and the temperature kept at $101^{\circ}$ to $103^{\circ} \mathrm{F}$. $\left(38.3^{\circ} \mathrm{C}\right.$. to $39.4^{\circ} \mathrm{C}$.). From 29.6 .60 Chloromycetin was begun, 1 capsule twice daily, and the next day the temperature fell to $98.6^{\circ} \mathrm{F}$. $\left(37.0^{\circ} \mathrm{C}\right.$.) 
and on 1.7 .60 to $97.8^{\circ} \mathrm{F}$. $\left(36.6^{\circ} \mathrm{C}\right.$.). Headache, bodyache and joint pains ceased and the reaction disappeared. We continued Chloromycetin for 2 more days.

Case No. 5. Choma, female, aged 25 years, an $\mathrm{L}_{3}$ case, with bacterial index $3+$ to $4+$. She was warded on 8.7 .60 with a temperature of $101^{\circ} \mathrm{F}$. $\left(38.3^{\circ} \mathrm{C}\right.$.) and was given PAT and calcium gluconate injections, but nodules, headache, and body ache appeared and a state of lepra reaction supervened. On 13.7.60 her temperature was $101.2^{\circ} \mathrm{F} .\left(38.4^{\circ} \mathrm{C}\right.$.) and at that time Chloromycetin was begun, 1 capsule twice daily, and continued thus for 5 days. On 14.7.60 her temperature was $100.4 \mathrm{~F}$. $\left(38.0^{\circ} \mathrm{C}\right.$.), the next day $98^{\circ} \mathrm{F}$. $\left(36.7^{\circ} \mathrm{C}\right.$. $)$, and then normal, and the reaction and its symptoms and signs disappeared. A relapse occurred on 28.10.60, when new nodules appeared, and the temperature rose to $100^{\circ} \mathrm{F}$. $\left(37.8^{\circ} \mathrm{C}\right.$.). This relapse yielded when Chloromycetin was given, I capsule twice daily for 5 days.

Case No. 6. Sirish Chandra Das, male, aged 30 years, a borderline case $\left(\mathrm{B}_{2}\right)$, with bacterial index $2+$. He was warded with flushed face and swollen hands and legs, and raised smooth shiny red patches, in fact a case of reaction in borderline leprosy. He was given an injection every second day of PAT up to a total of 5 injections, without effect. On 11.8.60 Chloromycetin was begun, 1 capsule twice daily, and kept up for 6 days. The patches and the swelling subsided and the reaction ceased.

Case No. 7. Probhat, male, aged 32 years, with bacterial index $3+$ to $4+$. He was warded with widespread body ulcers and lepra reaction, and given PAT and calcium gluconate injections, then Panmycin, and lastly Chloromycetin 1 capsule twice daily for 6 days. The temperature became normal and the reaction stopped, but the ulcers were slow in healing.

Case No. 8. Gorok Bahadur, male, aged 32 years, an L.2 case with bacterial index $1+$ to $3+$. He had fever, swelling of ear lobes and pain over the whole body. PAT had no effect, and on 15.10 .60 his temperature rose to $102.4^{\circ} \mathrm{F}$. $\left(39.1^{\circ} \mathrm{C}\right.$.). When Chloromycetin I capsule twice daily was given for 5 days, the reaction subsided completely.

Case No. 9. Lethro Soren, male, aged 30 years, an $\mathrm{L}_{3}$ case with bacterial index $2+$ to $3+$. He had a reaction without fever and pain, but swelling appeared of ear lobes and legs. From 22.10 .60 he was given Chloromycetin 1 capsule twice daily for 5 days, and the swelling and reaction subsided completely.

Case No. 10. Daud HASDAK, male, of 22 years, a Tuberculoid $\left(\mathrm{T}_{2}\right)$ reactional, with bacterial index $1+$, with fever, joint and body pains, swelling in hands and legs, and thickening of the ulnar nerves, so that on 25.10 .60 he was warded with temperature of $100.8^{\circ} \mathrm{F}$. $\left(38.2^{\circ} \mathrm{C}\right.$.). We gave Chloromycetin, 1 capsule twice daily for 5 days. The temperature became normal in 2 days, and pain and swelling subsided in 5 days, and the nerve thickening decreased.

Case No. 11. JANKı, female, aged 30 years, an $\mathrm{L}_{2}$ case with bacterial index $2+$ to $4+$. On 16.11 .60 she had a temperature of $100^{\circ} \mathrm{F}$. $\left(37.8^{\circ} \mathrm{C}\right.$. $)$, with headache, and pain over the whole body and was warded and given Chloromyceti 1 capsule twice daily for 6 days. Her temperature became normal in 4 days and the reaction was gone in 6 days.

Case No. 12. Khagendra, male, aged 32 years, an $\mathrm{L}_{3}$ case. On 2.11 .60 his temperature was $100.8^{\circ} \mathrm{F} .\left(38.2^{\circ} \mathrm{C}\right.$.), nodules appeared on his face and ear lobes, swelling of his legs, headache, body and joint pains. We gave Chloromycetin 1 capsule twice daily for 7 days, and in 5 days his temperature was normal, and the reaction abolished within 5 days.

Case $N$ o. 13. Gendra, male, aged 20 years, an $\mathrm{L}_{2}$ case, with bacterial index $2+$ to $3+$. On 2.11 .60 his temperature was $101^{\circ} \mathrm{F}$. $\left(38.3^{\circ} \mathrm{C}\right.$. $)$. New nodules appeared, he had ulcers in his throat and thickened ulnar nerves, headache, and body pain. We gave Chloromycetin capsules 1 twice daily for 9 days and the temperature became normal in 4 days. The reaction had subsided in 9 days, but the ulnar nerve remained thickened and painful. The throat ulcers healed.

Case No. 14. Suku ChORON, male, aged 50 years, an $\mathrm{L}_{3}$ case, with bacterial index $4+$, was warded on 28.10 .60 with temperature of $100^{\circ} \mathrm{F}$. $\left(37.8^{\circ} \mathrm{C}\right.$.), nodules, headache, body pain, and conjunctivitis. We gave Chloromycetin 1 capsule twice daily for 7 days and the temperature became normal in 5 days. In 7 days the reaction ceased. His eye condition improved. 
Case No. 15. Khandru, male, aged 32 years, an $\mathrm{L}_{2}$ case, with bacterial index $3+$, nodules, headache, body pain, and conjunctivitis. On 19.11 .60 his temperature was $99.6^{\circ} \mathrm{F}$. $\left(37.6^{\circ} \mathrm{C}\right.$.). We gave Chloromycetin I capsule twice daily for 6 days. The reaction ceased and the eye condition improved.

Case No. 16. Jongbik, male, aged 35 years, a $\mathrm{T}_{2}$ case. He had double conjunctivitis and corneal ulcer and we gave sulphathiazole, and penicillin injection, with a daily eye lotion of normal saline, and the application of penicillin eye ointment. Protargol 5\% also was tried, but his condition did not improve. Then we gave Chloromycetin 1 capsule twice daily for 5 days and the eyes improved.

Case No. 17. Geara, male, aged 35 years, an $\mathrm{L}_{3}$ case who also had cavitating pulmonary tuberculosis. He had fever, nodules, joint pains and swellings, and a corneal ulcer. We gave Chloromycetin 1 capsule twice daily for 6 days, and the fever and reaction ceased, nodules and joint pains and swelling decreased, and the eye condition improved.

\section{Conclusions}

We found that Chloromycetin acts upon all types of leprosy reaction. It has a definite beneficial effect on nerve pain, thickening of nerves, eye conditions, and ulcers, when these form a part of lepra reactions. Chloromycetin seems to us to be speedier and more effective than injections of potassium antimony tartrate or mercurochrome, and its mode of administration is easy ( 1 capsule of $250 \mathrm{mg}$. given by mouth twice daily for 6 days, more or less).

\section{Acknowledgement}

I wish to thank Rev. G. Fossland, Supt. of Santipara Leprosy Hospital, Miss B. A. Jorgensen, Miss Lucil.e Frickson, and hospital staff who were very helpful to me. 